\title{
New Directions for Hydrogen Storage: Sulphur Destabilized Sodium Aluminium Hydride
}

\author{
Drew A. Sheppard ${ }^{*}{ }^{a}$, Lars H. Jepsen ${ }^{b}$, Torben R. Jensen ${ }^{b}$, Mark Paskevicius $^{a}$ and Craig E. Buckley ${ }^{a}$ \\ Received (in $X X X, X X X)$ Xth $X X X X X X X X X 20 X X$, Accepted Xth $X X X X X X X X X 20 X X$ \\ ${ }_{5}$ DOI: 10.1039/b000000x
}

\begin{abstract}
Aluminium sulphide $\left(\mathrm{Al}_{2} \mathrm{~S}_{3}\right)$ is predicted to effectively destabilize sodium aluminium hydride $\left(\mathrm{NaAlH}_{4}\right)$ in a single-step endothermic hydrogen release reaction. The experimental results show unexpectedly complex desorption processes and a range of new sulphur containing hydrogen storage materials have been observed. The $\mathrm{NaAlH}_{4}-\mathrm{Al}_{2} \mathrm{~S}_{3}$ system releases a total of $4.9 \mathrm{wt} . \%$ of $\mathrm{H}_{2}$ that begins below $100{ }^{\circ} \mathrm{C}$ 10 without the need for a catalyst. Characterization via Temperature Programmed Desorption, in-situ Synchrotron Powder X-ray Diffraction, ex-situ X-ray Diffraction, ex-situ Fourier Transform Infrared Spectroscopy and hydrogen sorption measurements reveal complex decomposition processes that involve multiple new sulphur-containing hydride compounds. The system shows partial $\mathrm{H}_{2}$ reversibility, without the need for a catalyst, with a stable $\mathrm{H}_{2}$ capacity of $\sim 1.6$ wt.\% over 15 cycles in the temperature range of $15200{ }^{\circ} \mathrm{C}$ to $300{ }^{\circ} \mathrm{C}$. This absorption capacity is limited by the need for high $\mathrm{H}_{2}$ pressures (> 280 bar) to drive the absorption process at the high temperatures required for reasonable absorption kinetics. The large number of new phases discovered in this system suggests that destabilization of complex hydrides with metal sulphides is a novel but unexplored research avenue for hydrogen storage materials.
\end{abstract}

\section{Introduction}

20 Hydrogen is considered to be a key future energy carrier ${ }^{1}$ but its safe, compact and efficient storage are one of the key barriers to its widespread use. Hydrogen can be stored in the solid state using complex metal hydrides where the hydrogen is covalently bonded in complex anions such as $\mathrm{AlH}_{4}{ }^{-1}, \mathrm{AlH}_{6}{ }^{-3}, \mathrm{BH}_{4}{ }^{-1}$ and $\mathrm{NH}_{2}$ $25{ }^{1}$.

Of the class of complex metal hydrides known as complex Aluminium hydrides, or alanates, $\mathrm{NaAlH}_{4}$ is the most studied ${ }^{2-4}$ and has a theoretical hydrogen storage capacity of $7.5 \mathrm{wt} \%$ that is released via three reactions:

$$
\begin{array}{ll}
3 \mathrm{NaAlH}_{4} \rightarrow \mathrm{Na}_{3} \mathrm{AlH}_{6}+2 \mathrm{Al}+3 \mathrm{H}_{2} & \text { Reaction 1 } \\
\mathrm{Na}_{3} \mathrm{AlH}_{6} \rightarrow 3 \mathrm{NaH}+\mathrm{Al}+3 / 2 \mathrm{H}_{2} & \text { Reaction 2 } \\
\mathrm{NaH} \rightarrow \mathrm{Na}+1 / 2 \mathrm{H}_{2} & \text { Reaction 3 }
\end{array}
$$

${ }_{35}$ Reaction 1 and 2 can occur below $150{ }^{\circ} \mathrm{C}$ (with the aid of a catalyst) but Reaction 3 requires more than $400{ }^{\circ} \mathrm{C}$ and is not of practical use. As a result, not all of the hydrogen contained within $\mathrm{NaAlH}_{4}$ can be readily released and the useable hydrogen capacity is limited to the first two steps $\left(5.6 \mathrm{wt} . \% \mathrm{H}_{2}\right)$. To make 40 Reaction 1 and 2 reversible requires the addition of a catalytic phase ${ }^{3,5}$ that aids in the distortion of $\mathrm{Al}-\mathrm{H}$ bonds at the $\mathrm{NaAlH}_{4}$ interface. ${ }^{5}$ For example, the use of $\mathrm{TiCl}_{3}$ as a catalyst also results in an irreversible reaction with the $\mathrm{NaAlH}_{4}$ in a metathesis reaction: ${ }^{6}$

${ }_{45} 3 \mathrm{NaAlH}_{4}+\mathrm{TiCl}_{3} \rightarrow 3 \mathrm{NaCl}+x \mathrm{Al}+\mathrm{Al}_{3-x} \mathrm{Ti}+6 \mathrm{H}_{2}$ Reaction 4
The end result is that the practical capacity of $\mathrm{NaAlH}_{4}$ is typically reduced to the range of $3.0-4.5 \mathrm{wt} . \%{ }^{7,8}$

The major drawbacks of alanates are: (1) that they release 50 hydrogen in multiple desorption events (a disadvantage in engineering applications); (2) that not all the hydrogen can easily be released and (3) that the addition of catalysts reduces the practical hydrogen capacity.

A potential clue to an alternative approach to improve the 55 hydrogen storage properties of complex metal hydrides is in the reaction of $\mathrm{TiCl}_{3}$ with $\mathrm{NaAlH}_{4}$ (Reaction 4). Though the reaction is exothermic and irreversible, when $\mathrm{TiCl}_{3}$ is added in stoichiometric quantities, it does release all of the hydrogen in $\mathrm{NaAlH}_{4}$. Finding a similar reaction that releases all of the ${ }_{60}$ hydrogen in an endothermic process would mean that the hydrogen release is potentially reversible.

Alapati et al. ${ }^{9}$ used Density Functional Theory to screen for reversible hydrogen storage reactions based on all possible known combinations of 13 selected light elements and first row 65 transition metals. In a similar approach we have used the thermodynamic data ${ }^{10,11}$ and HSC software ${ }^{12}$ to explore the enthalpy of reaction between $\mathrm{NaAlH}_{4}$ and a range of metal oxides, metal halides and metal sulphides in an attempt to find a suitable reaction that releases all of the hydrogen in a single 70 endothermic step while maintaining high hydrogen content. These calculations suggested that $\mathrm{NaAlH}_{4}$ mixed with $\mathrm{Al}_{2} \mathrm{~S}_{3}$ could achieve the desired effect as shown in Reaction 5 (Figure 1):

$6 \mathrm{NaAlH}_{4}+\mathrm{Al}_{2} \mathrm{~S}_{3} \rightarrow 3 \mathrm{Na}_{2} \mathrm{~S}+8 \mathrm{Al}+12 \mathrm{H}_{2} \quad$ Reaction 5 


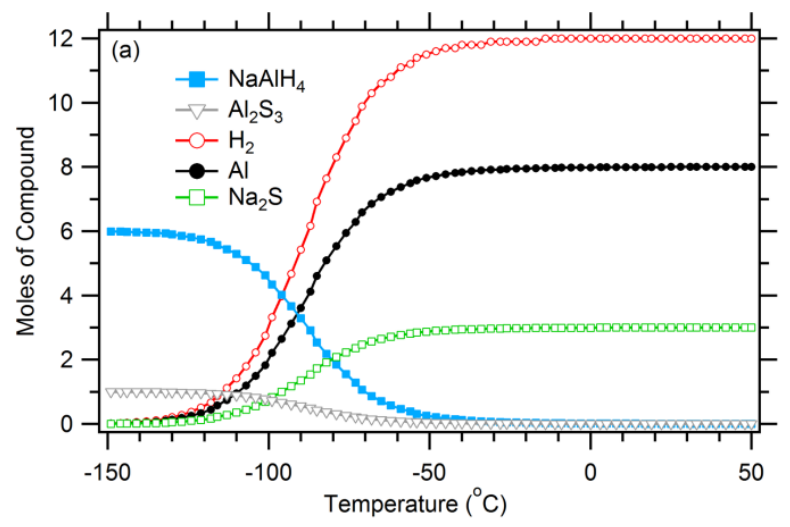

Fig 1. Predicted decomposition of $\mathrm{NaAlH}_{4}$ mixed with $\mathrm{Al}_{2} \mathrm{~S}_{3}(6$ to 1 mole ratio) as a function of temperature.

Reaction 5 has a theoretical $\mathrm{H}_{2}$ capacity of 5.1 wt.\% (1 bar 5 equilibrium temperature $\left.\left(T_{e q}\right)=-109{ }^{\circ} \mathrm{C}\right)$ compared to a theoretical value of 5.6 wt. $\%$ for pure $\mathrm{NaAlH}_{4}$ (first two steps: 1 bar $T_{e q}=33{ }^{\circ} \mathrm{C}$ and $105{ }^{\circ} \mathrm{C}$ ). ${ }^{10}$ Though the capacity is slightly lowered, all of the hydrogen release is predicted to occur in a single step; a significant advantage for engineering applications.

10 The addition of $\mathrm{Al}_{2} \mathrm{~S}_{3}$ also results in an increased volumetric density of hydrogen ( $74 \mathrm{~kg}$ of $\mathrm{H}_{2} / \mathrm{m}^{3}$ ) compared to pure $\mathrm{NaAlH}_{4}$ ( $71 \mathrm{~kg}$ of $\mathrm{H}_{2} / \mathrm{m}^{3}$ ). While the weight of a hydrogen tank for mobile applications is important, the volume the tank takes up within a passenger vehicle is also critical. By storing hydrogen at an 15 increased density, there is also a flow-on engineering benefit of reduced volume, weight and, hence, cost of the tank needed for storage. ${ }^{13}$ It should be noted that the theoretical enthalpy of Reaction 5 is $18.8 \mathrm{~kJ} / \mathrm{mol} \mathrm{H}_{2}$. This value is slightly too low for practical applications as it translates to an $\mathrm{H}_{2}$ equilibrium 20 pressure of $\sim 1515$ bar (fugacity of 3280 bar) at $100{ }^{\circ} \mathrm{C}$.

There are two important limitations associated with this predictive method. The first is that it cannot predict the true reaction if the reaction involves a previously unknown compound for which the thermodynamic properties are not known. ${ }_{25}$ Secondly, this method gives no information about the kinetics of reactions. Therefore, it may predict a reaction that is not observed experimentally due to kinetic limitations. ${ }^{9}$

Examination of the literature on sulphur-hydrogen compounds reveals a rich history of research into thiols (hydrocarbon 30 sulphur - hydrogen compounds) and thiolates (metal - sulphur hydrogen compounds) with the main focus being on catalysis, surface passivation and the fundamentals of self-assembled monolayer formation. These systems show that under the right conditions metal - sulphur - hydrogen systems can reversibly 35 release hydrogen without the need for catalysts. ${ }^{14,15}$

The thermodynamic predictions of complex hydrides mixed with metal sulphides and the experimental work of hydrogen release from thiols and thiolates suggests that a new class of sulphur based hydrogen storage materials that do not require the addition 40 of catalysts may be viable. The potential of sulphur based materials and their application in hydrogen storage systems is a new approach that has not previously been considered. Here we present the first results on the novel hydrogen storage systems $\mathrm{NaAlH}_{4}-\mathrm{Al}_{2} \mathrm{~S}_{3}$ that show a onset temperature for hydrogen 45 release below $100{ }^{\circ} \mathrm{C}$ and partial hydrogen reversibility without the need for catalysts.

\section{Experimental}

\section{Synthesis}

All handling and storage of chemicals was performed in argon50 filled glove-boxes equipped with circulation purifiers. Sample preparation: $\mathrm{NaH}$ (95\%, Aldrich), $\mathrm{NaAlH}_{4}$ (95\%, Aldrich), and $\mathrm{Al}_{2} \mathrm{~S}_{3}$ (98\%, Aldrich) were used as received.

Samples of $\mathrm{NaAlH}_{4}-\mathrm{Al}_{2} \mathrm{~S}_{3}(6: 1)$ and $\mathrm{NaH}-\mathrm{Al}_{2} \mathrm{~S}_{3}$ (6:1) for in-situ synchrotron powder X-ray diffraction (SR-XRD) were ball milled 55 using a Fritz Pulveritsette 4 planetary ball mill, a tungsten carbide (WC) vial $(80 \mathrm{~mL})$ and $10 \mathrm{~mm}$ diameter balls in a ball-to-powder (BTP) ratio of 35:1. The total milling time was 20 minutes ball milling 2 minutes of ball milling and 2 minutes of break, repeated 10 times.

${ }_{60}$ Samples of $\mathrm{NaAlH}_{4}-\mathrm{Al}_{2} \mathrm{~S}_{3}$ (6:1) for hydrogen absorption measurements were prepared using a PQ-N04 planetary mill (Across International) using a stainless steel vial $(100 \mathrm{~mL})$ and stainless steel balls (diameter: $10 \mathrm{~mm}$ ). $\mathrm{NaAlH}_{4}$ and $\mathrm{Al}_{2} \mathrm{~S}_{3}$ (6:1, $1 \mathrm{~g}$ ) were also cryogenically milled at $77 \mathrm{~K}$ using a Spex 6850 65 freezer mill using a 2 minute milling, 1 minute cooling cycle for a total of 30 minutes of milling. The milling rod speed was set at 10 impacts per second per side. The high impact rate results in high energy milling while the cryogenic conditions prevents decomposition of the sample that can result from high energy 70 ambient milling.

Other than potential contamination from the milling media, no catalysts were added to the system. All further references to the $\mathrm{NaAlH}_{4}-\mathrm{Al}_{2} \mathrm{~S}_{3}$ and $\mathrm{NaH}-\mathrm{Al}_{2} \mathrm{~S}_{3}$ systems are for those mixed in a 6:1 molar ratio.

\section{${ }_{75}$ Characterisation}

In-situ SR-XRD data $(\lambda=0.9892 \AA$ and $1.1011 \AA)$ were measured at Beamline I711 at the MAX-II synchrotron in the research laboratory MAX-lab, Lund, Sweden with a MAR165 $\mathrm{CCD}$ detector system. The samples were mounted in sapphire ${ }_{80}\left(\mathrm{Al}_{2} \mathrm{O}_{3}\right)$ single crystal tubes $(1.09 \mathrm{~mm}$ o.d., $0.79 \mathrm{~mm}$ i.d. $)$ in an argon filled glovebox using a specially designed sample holder. ${ }^{16}$ The in-situ SR-XRD measurements were performed for $\mathrm{NaAlH}_{4}-\mathrm{Al}_{2} \mathrm{~S}_{3}$ and $\mathrm{NaH}-\mathrm{Al}_{2} \mathrm{~S}_{3}$ heated from room temperature (RT) to $500{ }^{\circ} \mathrm{C}\left(5^{\circ} \mathrm{C} / \mathrm{min}\right)$ under dynamic vacuum.

${ }_{85}$ Ex-situ SR-XRD data was collected from a sample sealed in a borosilicate capillary ( $0.3 \mathrm{~mm}$ o.d.) at the Australian Synchrotron, Melbourne, Australia $(\lambda=1.000 \AA)$ with a Mythen microstrip detector.

Laboratory-based XRD patterns of hydrogen cycled $\mathrm{NalH}_{4}-\mathrm{Al}_{2} \mathrm{~S}_{3}$ 90 were performed using a Bruker D8 Advance diffractometer $(\lambda=$ $1.5406 \AA$ ) with a $2 \theta$ range of 10 to $70^{\circ}$. The samples were loaded into an XRD sample holder and sealed with a poly(methylmethacrylate) (PMMA) airtight bubble within a glovebox to prevent oxygen/moisture contamination during data 95 collection. The PMMA airtight bubble results in broad humps in XRD patterns centred at $10^{\circ}$ and $20^{\circ} 2 \theta$, respectively. Quantitative analysis of one unknown phase was achieved by using an internal standard to calibrate a PONKCS (Partial Or No Known Crystal Structure) phase. ${ }^{17}$ This method substitutes a 100 crystal structure for a set of peaks (or a Le Bail fit) associated with an unknown phase that may be scaled in unison similar to the set of structure factors derived from a crystal structure. Once the PONKCS phase is calibrated with an internal standard, it can 
be used for quantitative phase analysis. Rietveld refinement and unit cell indexing was performed using version 4.2 of the TOPAS

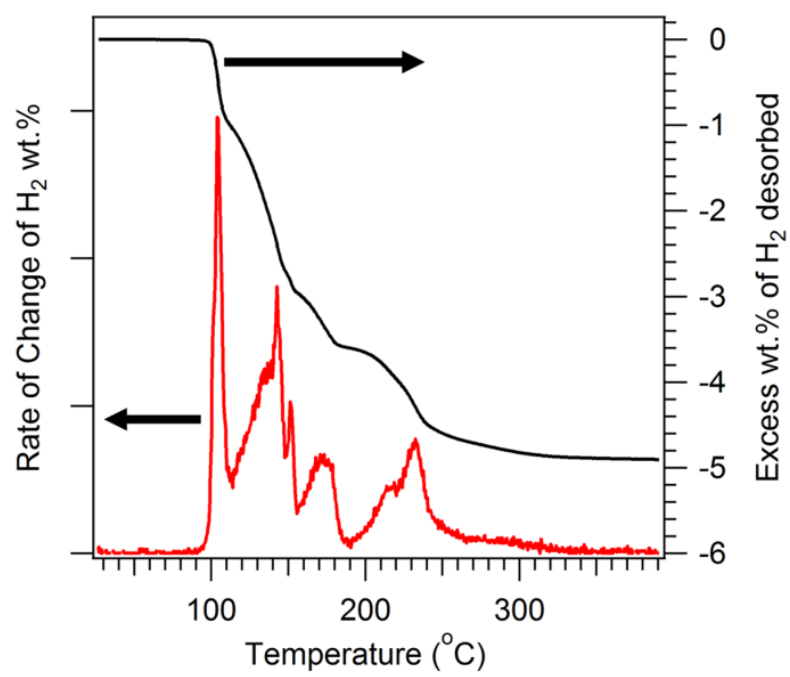

Fig 2. Temperature Programmed Desorption (TPD-MS) of $\mathrm{NaAlH}_{4}-\mathrm{Al}_{2} \mathrm{~S}_{3}$ 5 ball-milled for $6 \mathrm{~h}$. Heating rate $=1^{\circ} \mathrm{C} / \mathrm{min}$.

software (Bruker-AXS).

Fourier transform infrared spectroscopy (FTIR) spectra were collected using a Bruker IFS 66 FT-IR with 64 background and 64 sample scans. The spectrometer was purged with dry nitrogen 10 and samples were prepared by encapsulation within pressed $\mathrm{KBr}$ pellets.

Temperature Programmed Desorption Mass Spectrometry (TPDMS) on $\mathrm{NaAlH}_{4}-\mathrm{Al}_{2} \mathrm{~S}_{3}$ was performed on a PCT-Pro E\&E (HyEnergy) coupled to a quadrupole mass spectrometer residual gas 15 analyser (Stanford Research Systems RGA 300) that monitored from 1 to 58 atomic mass units (AMU). For each measurement, approximately $30 \mathrm{mg}$ of sample was outgassed at $3 \times 10^{-7}$ bar and $25{ }^{\circ} \mathrm{C}$ overnight. While still under vacuum, the samples were heated up to $375^{\circ} \mathrm{C}$ at a heating rate of $1{ }^{\circ} \mathrm{C} / \mathrm{min}$.

${ }_{20}$ Ex-situ XRD and FTIR patterns were collected on the $\mathrm{NaAlH}_{4}$ $\mathrm{Al}_{2} \mathrm{~S}_{3}$ system, where repeat TPD-MS measurements were halted at $115,150,160,195,275$ and $375^{\circ} \mathrm{C}$, and then cooled quickly to room temperature. These samples shall be referred to as TPD115, TPD-150, TPD-160, TPD-195, TPD-275 and TPD-375, 25 respectively.

The $\mathrm{H}_{2}$ release and uptake for $\mathrm{NaAlH}_{4}-\mathrm{Al}_{2} \mathrm{~S}_{3}$ were measured on two separate custom-made Sieverts/volumetric instruments. Both instruments utilized Rosemount pressure transducers (Model $3051 \mathrm{~S}$ ) with an accuracy of $0.01 \%$ of their maximum pressure 30 (150 and 690 bar, respectively). Initially, samples of $\mathrm{NaAlH}_{4}$ $\mathrm{Al}_{2} \mathrm{~S}_{3}$ were evacuated at room temperature and then desorbed of $\mathrm{H}_{2}$ by heating to $380{ }^{\circ} \mathrm{C}$ at $11{ }^{\circ} \mathrm{C} / \mathrm{min}$ under either their evolved hydrogen pressure (to confirm wt. $\%$ of $\mathrm{H}_{2}$ desorbed) or vacuum. Absorption measurements were performed by loading a known 35 reference volume to the target pressure and then opening it to the sample volume. The absorption pressures quoted in the text are the final pressures the system reached after absorption was complete.

Safety warning: Handling of these samples comprises a number 40 of safety hazards. $\mathrm{NaAlH}_{4}$ reacts violently with water and may spontaneously combust in air. Exposure of $\mathrm{Al}_{2} \mathrm{~S}_{3}$ (and metal sulphides in general) to water or atmospheric moisture releases toxic $\mathrm{H}_{2} \mathrm{~S}$ gas.

\section{Results}

${ }_{45}$ TPD-MS on $\mathrm{NaAlH}_{4}-\mathrm{Al}_{\mathbf{2}} \mathrm{S}_{\mathbf{3}}(6: 1)$

TPD-MS up to $390{ }^{\circ} \mathrm{C}$ of $\mathrm{NaAlH}_{4}-\mathrm{Al}_{2} \mathrm{~S}_{3}$ milled for $6 \mathrm{~h}$ (Figure 2) showed multiple $\mathrm{H}_{2}$ release events below $300{ }^{\circ} \mathrm{C}$, with the first small release beginning below $\sim 100{ }^{\circ} \mathrm{C}$. The sample released a total of $4.91 \mathrm{wt} . \%$ of $\mathrm{H}_{2}$ in good agreement with the theoretically 50 predicted value of $5.1 \mathrm{wt} . \%$. Given the presence of sulphur in these samples, the potential release of $\mathrm{H}_{2} \mathrm{~S}$ or other sulphanes is of concern due to their toxicity. Additionally, the formation and loss of $\mathrm{H}_{2} \mathrm{~S}$ from the system would reduce the cyclic $\mathrm{H}_{2}$ capacity. However, TPD-MS showed that only $\mathrm{H}_{2}$ was released for all 55 samples when adequately outgassed prior to measurement. Insufficient degassing resulted in $\mathrm{H}_{2}, \mathrm{H}_{2} \mathrm{O}$ and $\mathrm{H}_{2} \mathrm{~S}$ release below $100{ }^{\circ} \mathrm{C}$ due to the reaction between atmospheric moisture physisorbed on the sample cell and the sample. The multiple $\mathrm{H}_{2}$ release events observed in Figure 2 are in contrast to the single ${ }_{60}$ decomposition step predicted by the thermodynamic software HSC. ${ }^{12}$ The discrepancy is not entirely unexpected, however, as the software can only predict reaction pathways including known phases, and does not include any kinetic considerations.

XRD of the product after decomposition to $390{ }^{\circ} \mathrm{C}$, Figure S1, ${ }_{65}$ showed only the expected decomposition products of $\mathrm{Na}_{2} \mathrm{~S}$ and $\mathrm{Al}$ (see Reaction 5). One possible explanation for detecting multiple desorption events is hindered kinetics in parts of the sample due to insufficient milling. ${ }^{18}$ This could be a result of inadequate mixing of the starting reagents due to the large 70 volume difference between them $\left(\mathrm{NaAlH}_{4}=77\right.$ vol. $\%, \mathrm{Al}_{2} \mathrm{~S}_{3}=23$ vol.\%). To explore this hypothesis further, several $\mathrm{NaAlH}_{4}-\mathrm{Al}_{2} \mathrm{~S}_{3}$ samples were synthesized with different milling times and BTP ratios. Decreasing the milling time to $3 \mathrm{~h}(\mathrm{BTP}=15: 1)$, Figure S2 (a), again resulted in multiple $\mathrm{H}_{2}$ release events. However, in this 75 case, the temperatures and relative intensities of the desorption events are distinctly different. This suggests that decomposition of the $\mathrm{NaAlH}_{4}-\mathrm{Al}_{2} \mathrm{~S}_{3}$ system involves competing kinetic and thermodynamic pathways. In other complex hydride systems, the kinetics are known to be controlled by bulk diffusion rates. ${ }^{19,} 20$ 80 However, in the $\mathrm{NaAlH}_{4}-\mathrm{Al}_{2} \mathrm{~S}_{3}$ system the change in diffusion length is responsible for the improved kinetics as the bulk diffusion rates can only be changed by altering the chemical composition of the sample. ${ }^{19}$

Increasing the milling time to $15 \mathrm{~h}(\mathrm{BTP}=90: 1)$ resulted in the 85 loss of the first hydrogen release event, Figure S2 (c), and XRD after milling showed the presence of $\sim 3.5 \mathrm{wt} \% \mathrm{Al}$ that was absent in samples milled for shorter durations. This result shows that prolonged energetic milling resulted in partial decomposition of the starting reagents. The remaining hydrogen desorption 90 events were similar to the sample ball milled for $6 \mathrm{~h}$ and the cryomilled sample, Figure S2 (d). These results suggest that the multiple hydrogen desorption events observed are due to the formation and decomposition of intermediate phases that were not predicted in the initial thermodynamic calculations.

\section{${ }_{95}$ In-situ SR-XRD of $\mathrm{NaAlH}_{\mathbf{4}}-\mathrm{Al}_{2} \mathrm{~S}_{3}$}

To gain further insight into the multiple decomposition pathways, in-situ synchrotron XRD was performed on $\mathrm{NaAlH}_{4}-\mathrm{Al}_{2} \mathrm{~S}_{3}$ during 
decomposition under vacuum at a heating rate of $5{ }^{\circ} \mathrm{C} / \mathrm{min}$ (Figure 3(a)). The decomposition pathway is complex, with multiple phase transformations (mirroring the TPD-MS results), and the formation of an array of as-yet unknown phases. At 132 ${ }_{5}^{\circ} \mathrm{C}$ reflections from $\mathrm{NaAlH}_{4}$ and $\mathrm{Al}_{2} \mathrm{~S}_{3}$ begin to decrease in intensity and three new compounds form: $\mathrm{Al}$ and two unidentified phases that we have designated $\alpha$ and $\beta$ respectively. The $\alpha-$ phase has only very low intensity peaks, begins to decompose at
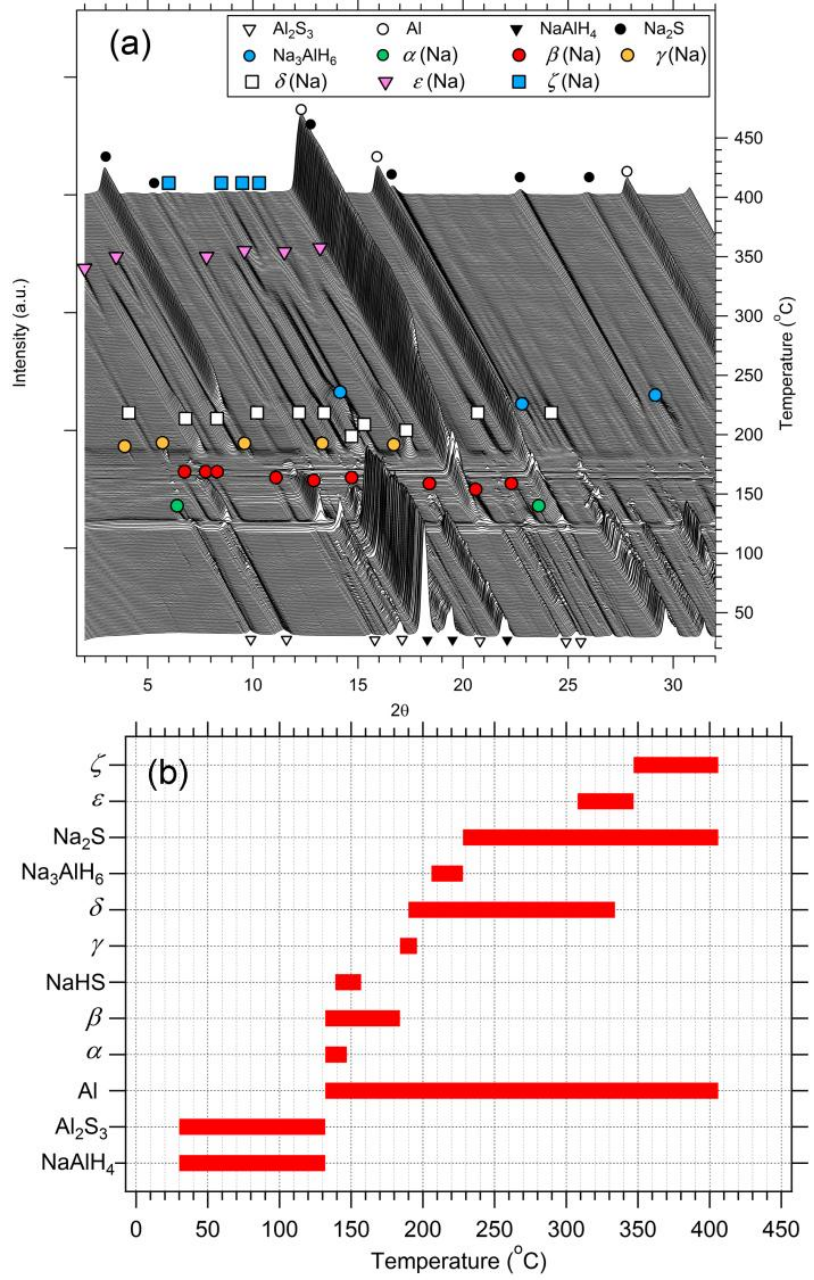

10 Fig 3. (a) In-situ $\mathrm{SR}-\mathrm{XRD}$ of $\mathrm{NaAlH}_{4}-\mathrm{Al}_{2} \mathrm{~S}_{3}$ decomposed under vacuum at a heating rate of $5{ }^{\circ} \mathrm{C} / \mathrm{min}, \lambda=0.9892 \AA$ and (b) a summary of the stable temperature ranges for the phases observed during decomposition.

$139^{\circ} \mathrm{C}$ and is associated with the formation of an XRD peak at $2 \theta$ $\sim 18.6^{\circ}$ (this peak is obscured by the intense $\mathrm{NaAlH}_{4}$ peaks in ${ }_{15}$ Figure 3 (a)). This peak corresponds to the high-temperature cubic phase of NaHS that is stable above $\sim 92{ }^{\circ} \mathrm{C} .{ }^{21}$ However, the quality of the data and the high degree of peak overlap with other phases makes this assignment tentative. The NaHS peak continues to grow until the $\alpha$-phase disappears at $147^{\circ} \mathrm{C}$. The $\beta$ 20 - phase and NaHS begin to decompose at $150{ }^{\circ} \mathrm{C}$ with $\mathrm{NaHS}$ completely decomposed by $157{ }^{\circ} \mathrm{C}$. The $\beta$ - phase continues to slowly decrease in intensity and disappears by $184{ }^{\circ} \mathrm{C}$ where peaks from $\gamma$ begin to form. The $\gamma$-phase is short-lived and is gone by $196{ }^{\circ} \mathrm{C}$. At $190{ }^{\circ} \mathrm{C}$, reflections from yet another unknown ${ }_{25}$ phase, $\delta$, form and reflections from $\mathrm{Na}_{3} \mathrm{AlH}_{6}$ also begin to form at $206{ }^{\circ} \mathrm{C}$. The formation of $\mathrm{Na}_{2} \mathrm{~S}$ begins at $228{ }^{\circ} \mathrm{C}$ and coincides with the disappearance of $\mathrm{Na}_{3} \mathrm{AlH}_{6}$, a decrease in the intensity of the $\delta$ - phase and an increase in the intensity of Al. The remaining $\delta$ phase peaks remain stable up to $308{ }^{\circ} \mathrm{C}$ where weak 30 reflections from an unknown phase, $\varepsilon$, appear. This conversion to the $\varepsilon$-phase is quite slow and the last reflections from the $\delta$ phase finally disappear at $334{ }^{\circ} \mathrm{C}$. At $347{ }^{\circ} \mathrm{C}$ reflections from the $\varepsilon$ - phase decrease in intensity and weak reflections from another unknown $\zeta$ - phase appear. The reflections from $\mathrm{Na}_{2} \mathrm{~S}, \mathrm{Al}$ and the $35 \zeta$ - phase are stable up until the experiment ends at $406{ }^{\circ} \mathrm{C}$. Given the complexity of the decomposition pathway, a summary of the phases and the temperature range over which they are stable is shown in Figure 3(b). With the possible exception of the $\alpha-$ phase, none of the unknown phases match any known ${ }_{40} \mathrm{Na} / \mathrm{Al} / \mathrm{S} / \mathrm{O} / \mathrm{H}$ compounds. The $\alpha$ - phase may match $\mathrm{NaOH}$ but the low intensity of the peaks and the large number of overlapping peaks makes definitive determination difficult.

As a comparison, in-situ SR-XRD was also performed on $\mathrm{NaH}$ $\mathrm{Al}_{2} \mathrm{~S}_{3}$ (Figure S3). This reaction is predicted to be exothermic ${ }_{45}\left(\Delta H=-37.7 \mathrm{~kJ} / \mathrm{mol} . \mathrm{H}_{2}\right)^{12}$ but in-situ $\mathrm{SR}-\mathrm{XRD}$ should reveal if the unknown phases observed in the decomposition of $\mathrm{NaAlH}_{4}-\mathrm{Al}_{2} \mathrm{~S}_{3}$ are due to the interaction between $\mathrm{NaAlH}_{4}$ and $\mathrm{Al}_{2} \mathrm{~S}_{3}$ or the interaction between $\mathrm{NaH}$ and $\mathrm{Al}_{2} \mathrm{~S}_{3}$ after $\mathrm{NaAlH}_{4}$ has begun to decompose. Figure $\mathrm{S} 3$ reveals that $\mathrm{NaH}$ begins to react with ${ }_{50} \mathrm{Al}_{2} \mathrm{~S}_{3}$ at $195^{\circ} \mathrm{C}$ in a single-step reaction with the direct formation of $\mathrm{Na}_{2} \mathrm{~S}$ and $\mathrm{Al}$ according to reaction 6 :

$$
6 \mathrm{NaH}+\mathrm{Al}_{2} \mathrm{~S}_{3} \rightarrow 3 \mathrm{Na}_{2} \mathrm{~S}+2 \mathrm{Al}+3 \mathrm{H}_{2} \quad \text { Reaction } 6
$$

${ }_{55}$ This indicates that the unknown phases seen during in-situ SRXRD of $\mathrm{NaAlH}_{4}-\mathrm{Al}_{2} \mathrm{~S}_{3}$ are in-fact due to alternate chemical reactions from the complex sulphur chemistry, where a range of different compounds may be formed as intermediates.

\section{Ex-situ FTIR and XRD on $\mathrm{NaAlH}_{4}-\mathrm{Al}_{2} \mathrm{~S}_{3}$}

${ }_{60}$ Ex-situ XRD after TPD to $115{ }^{\circ} \mathrm{C}$ (TPD-115), Figure 4 (a)(i), only shows the presence of $\mathrm{NaAlH}_{4}$ and $\mathrm{Al}$. All traces of $\mathrm{Al}_{2} \mathrm{~S}_{3}$ have disappeared and no other sulphur containing compounds are present, suggesting that all of the sulphur is bound within amorphous or nanocrystalline phases. No other sodium ${ }_{65}$ containing compounds are evident, which suggests that all of the sodium from $\mathrm{NaAlH}_{4}$ decomposition is present in the amorphous or nanocrystalline sulphur containing compound. Rietveld refinement reveals that $\mathrm{NaAlH}_{4}$ comprises $\sim 78$ wt. $\%$ of the crystalline portion of the sample and $\mathrm{Al} \sim 22 \mathrm{wt} . \%$. The $1.0 \mathrm{wt} . \%$ 70 of $\mathrm{H}_{2}$ lost in this temperature range is insufficient to account for the mass ratio of $\mathrm{NaAlH}_{4}$ and $\mathrm{Al}$ in the crystalline products. This suggests that either some of the crystalline $\mathrm{Al}$ comes from $\mathrm{Al}_{2} \mathrm{~S}_{3}$ or that there is some hydrogen remaining in the amorphous/nanocrystalline phase. Ex-situ FTIR, Figure 4 (b)(i), 75 shows that, after TPD at $115^{\circ} \mathrm{C}$, absorption bands associated with $\mathrm{NaAlH}_{4}$ at $1678,900,740$ and the shoulder at $\sim 660 \mathrm{~cm}^{-1}$ are still present ${ }^{22}$ and that the three bands at 503, 459 and $422 \mathrm{~cm}^{-1}$ associated with pure $\mathrm{Al}_{2} \mathrm{~S}_{3}$ (Figure $\mathrm{S} 4$ (a)) have disappeared. In their place is a broad absorption band extending from $480 \mathrm{~cm}^{-1}$ to ${ }_{80} 400 \mathrm{~cm}^{-1}$ and centered at $424 \mathrm{~cm}^{-1}$. No other changes occur in the FTIR pattern that can be associated with the amorphous or nanocrystalline sulphur containing phase. For comparison, FTIR of pure $\mathrm{NaAlH}_{4}$ (Figure $\mathrm{S} 4$ (b)) and $6 \mathrm{~h}$ ball-milled $\mathrm{NaAlH}_{4}$ $\mathrm{Al}_{2} \mathrm{~S}_{3}$ (Figure $\mathrm{S} 4(\mathrm{c})$ ) are also included. 
Ex-situ XRD on TPD-150, Figure 4 (a)(ii), shows $\mathrm{NaAlH}_{4}, \mathrm{Al}$ and the $\delta$ - phase. The room-temperature rhombohedral polymorph of NaHS was also indentified. ${ }^{19}$ Using the PONKCS (Partial Or No Known Crystal Structure) method, ${ }^{17}$ as outlined in 5 the Experimental Characterisation section, quantitative phase analysis yielded $\mathrm{NaAlH}_{4} \sim 10$ wt. $\%$, NaHS $\sim 7$ wt. $\%$, Al $\sim 20$ wt. $\%$ and the $\delta$-phase $\sim 63$ wt. $\%$. Ex-situ FTIR, Figure 4 (b)(ii), shows a pronounced decrease in the intensity of the main $\mathrm{NaAlH}_{4}$ bands and the formation of a shoulder at $\sim 1606 \mathrm{~cm}^{-1}$. Bands also 10 formed at $\sim 823,690,571$,
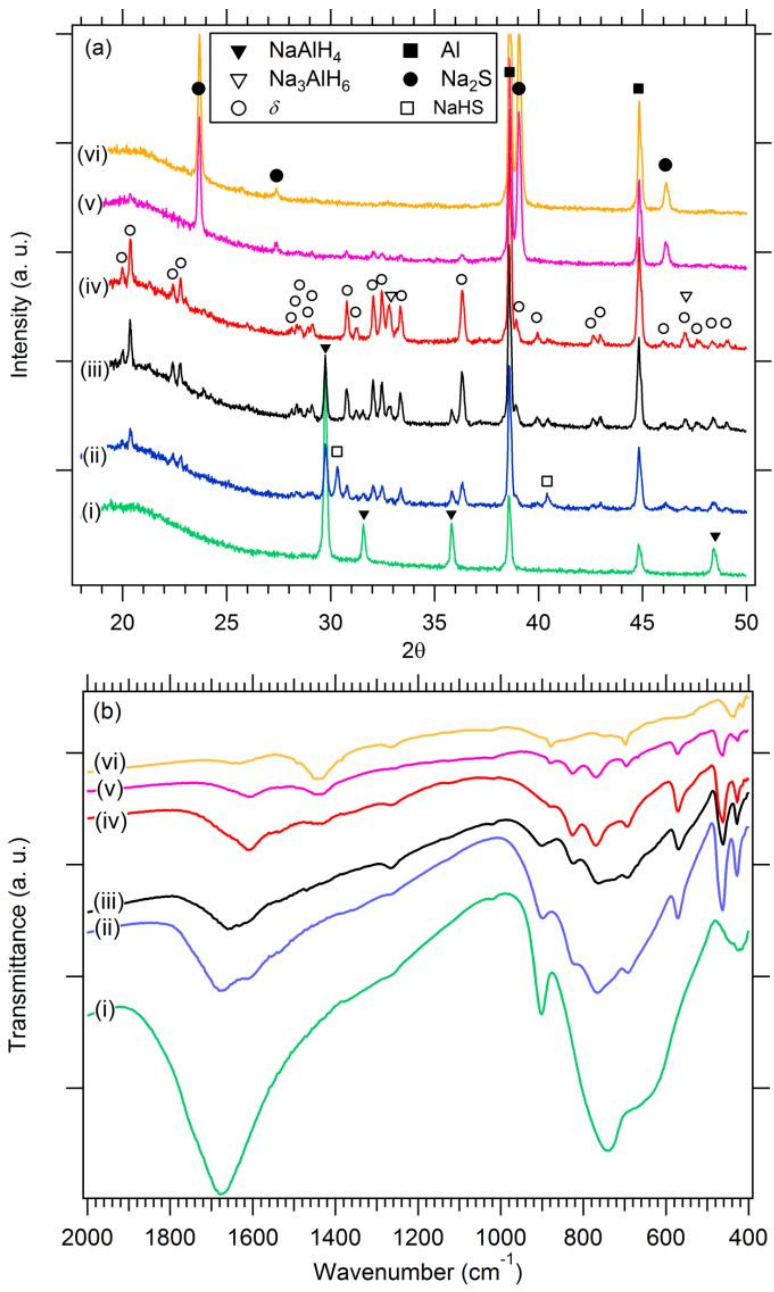

Fig 4. (a) $E x$-situ XRD $(\lambda=1.5406 \AA)$ of $\mathrm{NaAlH}_{4}-\mathrm{Al}_{2} \mathrm{~S}_{3}$ decomposed under vacuum at a heating rate of $1{ }^{\circ} \mathrm{C} / \mathrm{min}$ up to (i) $115^{\circ} \mathrm{C}$, (ii) $150{ }^{\circ} \mathrm{C}$, (iii) $165^{\circ} \mathrm{C}$, (iv) $195^{\circ} \mathrm{C}$, (v) $275^{\circ} \mathrm{C}$ and (vi) $375^{\circ} \mathrm{C}$. (b) The

15 corresponding ex-situ FTIR of $\mathrm{NaAlH}_{4}-\mathrm{Al}_{2} \mathrm{~S}_{3}$ decomposed under vacuum at a heating rate of $1{ }^{\circ} \mathrm{C} / \mathrm{min}$ up to (i) $115^{\circ} \mathrm{C}$, (ii) $150{ }^{\circ} \mathrm{C}$, (iii) $165^{\circ} \mathrm{C}$, (iv) $195^{\circ} \mathrm{C}$, (v) $275^{\circ} \mathrm{C}$ and (vi) $375^{\circ} \mathrm{C}$.

463 and $428 \mathrm{~cm}^{-1}$. NaHS identified by ex-situ XRD in trace levels and ex-situ FTIR cannot resolve the typical NaHS FTIR active 20 modes at 2544,1850 and $\sim 450 \mathrm{~cm}^{-1}$. ${ }^{23}$ So we can attribute the new bands in the FTIR pattern to the only other compound present, $\delta$ - phase.

Ex-situ XRD on TPD-160, Figure 4 (a)(iii), shows that the NaHS phase has disappeared, also shows a decrease in $\mathrm{NaAlH}_{4}$ content 25 to 4.1 wt.\%, the appearance of $\mathrm{Na}_{3} \mathrm{AlH}_{6}$ (1.5 wt.\%), a decrease in $\mathrm{Al}$ content to $14.2 \mathrm{wt} \%$ and an increase in the $\delta$-phase to 80.2 wt.\%. The decomposition of NaHS between 150 and $160{ }^{\circ} \mathrm{C}$ is somewhat unexpected given that the melting point of NaHS is $350{ }^{\circ} \mathrm{C}^{24}$ The ex-situ FTIR, Figure 4 (b)(iii) is similar to the 30 previous pattern but with a slight enhancement of the shoulder at $1606 \mathrm{~cm}^{-1}$ at the expense of the $\mathrm{NaAlH}_{4}$ peak at $1678 \mathrm{~cm}^{-1}$. This represents a decrease in the stretching vibrations of $\mathrm{AlH}_{4}{ }^{-1}$. This shift is not related to the formation of $\mathrm{Na}_{3} \mathrm{AlH}_{6}$ or the $\mathrm{AlH}_{6}^{-3}$ anion, as the main band for $\mathrm{Na}_{3} \mathrm{AlH}_{6}$ at $1275-1300 \mathrm{~cm}^{-1}$ is 35 absent. $^{22,25}$ A similarly small decrease in the frequency of $\mathrm{AlH}_{4}{ }^{-1}$ stretching vibrations has been seen during the decomposition of $\mathrm{KAlH}_{4},{ }^{26}$ which was attributed to an increase in co-ordination number about the $\mathrm{Al}$ atom and the formation of $\mathrm{K}_{y} \mathrm{AlH}_{x}(y \geq 1$ and $x>4$ ). However it should be noted that relatively small 40 structural changes in the local environment of the $\mathrm{AlH}_{4}^{-1}$ anion can also cause shifts in the position of the stretching band at 1675 $\mathrm{cm}^{-1} \cdot{ }^{20}$

Ex-situ XRD on TPD-195, Figure 4 (a)(iv) shows the complete disappearance of $\mathrm{NaAlH}_{4}$ and an increase in $\mathrm{Na}_{3} \mathrm{AlH}_{6}$ to $\sim 4.6$

$45 \mathrm{wt} . \%$, a slight decrease in $\mathrm{Al}(17.8 \mathrm{wt} . \%)$ and a slight decrease in the $\delta$-phase (77.6 wt.\%). The associated ex-situ FTIR, Figure 4 (b)(iv) clearly shows the band at $1606 \mathrm{~cm}^{-1}$ has been growing and reveals that bands associated with $\mathrm{NaAlH}_{4}$ are absent. A band has also begun to form at $\sim 1440 \mathrm{~cm}^{-1}$. The bands below $600 \mathrm{~cm}^{-1}$ 50 remain unchanged while the bands at 827,767 and $692 \mathrm{~cm}^{-1}$ become more clearly resolved.

Ex-situ XRD on TPD-275, Figure $4(\mathrm{a})(\mathrm{v})$, shows the formation of $\mathrm{Na}_{2} \mathrm{~S}(\sim 38.1$ wt.\%), an increase in $\mathrm{Al}(\sim 38.4$ wt.\%) and a decrease in the $\delta$-phase ( 23.5 wt.\%). FTIR, Figure $4(\mathrm{~b})(\mathrm{v})$, 55 shows that the band at $1440 \mathrm{~cm}^{-1}$ has increased in intensity relative to all other bands and that the band at $1606 \mathrm{~cm}^{-1}$ has decreased in intensity.

Ex-situ XRD of TPD-375, Figure 4 (a)(vi), shows complete removal of the $\delta$ - phase. FTIR, Figure 4 (b)(vi), shows further 60 enhancement of the band at $1440 \mathrm{~cm}^{-1}$ at the expense of the $\delta$ phase band at $1606 \mathrm{~cm}^{-1}$. Bands associated at $827 \mathrm{~cm}^{-1}, 769 \mathrm{~cm}^{-1}$, $571 \mathrm{~cm}^{-1}, 463 \mathrm{~cm}^{-1}$ and $426 \mathrm{~cm}^{-1}$ have disappeared, whilst the bands at $879 \mathrm{~cm}^{-1}$ and $698 \mathrm{~cm}^{-1}$ have remained. In addition, the three bands below $500 \mathrm{~cm}^{-1}$ have transformed into a single band 65 at $436 \mathrm{~cm}^{-1}$. FTIR performed on pure $\mathrm{Na}_{2} \mathrm{~S}$ (Figure $\mathrm{S} 4(\mathrm{~d}$ )) revealed that only the band at $1440 \mathrm{~cm}^{-1}$ can unambiguously be attributed to $\mathrm{Na}_{2} \mathrm{~S}$. As a result, the other bands present after decomposition cannot be ruled out as being due to minor impurity phases such as oxides.

70 Based on TPD-MS and the ex-situ XRD and FTIR measurements, some conclusions can be drawn about the nature of the $\delta$-phase: (1) The $\delta$-phase contains hydrogen and; (2) the hydrogen is coordinated to $\mathrm{Al}$, probably as $\mathrm{AlH}_{4}^{-1}$, rather than bound to $\mathrm{S}$ as a hydrosulphide ion, $\mathrm{SH}^{-1}$. In-situ $\mathrm{SR}-\mathrm{XRD}$ and ex-situ XRD also 75 provide some interesting insights into the role of NaHS in the system. There are some discrepancies in the decomposition observed via in-situ SR-XRD compared to ex-situ XRD. The primary differences are that the formation of the $\delta$-phase and the formation of $\mathrm{Na}_{3} \mathrm{AlH}_{6}$ occur $\sim 30-40{ }^{\circ} \mathrm{C}$ lower in temperature 80 in the ex-situ XRD measurements compared to in-situ SR-XRD. This difference can readily be explained by the difference in heating rate used in the ex-situ XRD measurements $\left(1{ }^{\circ} \mathrm{C} / \mathrm{min}\right)$ and the in-situ SR-XRD measurements $\left(5^{\circ} \mathrm{C} / \mathrm{min}\right)$. However, the narrow temperature range for the formation and decomposition of $85 \mathrm{NaHS}$ is near identical for both sets of measurements. Combined 
with the fact that NaHS disappears well below its melting point suggests that it is undergoing decomposition via a chemical reaction with a very low activation energy and rapid kinetics. However, further experimental work is needed to verify this.

\section{${ }_{5}$ Hydriding Properties of $\mathrm{NaAlH}_{4}-\mathrm{Al}_{2} \mathrm{~S}_{3}$}

Hydrogen absorption was attempted after decomposing $\mathrm{NaAlH}_{4}$ $\mathrm{Al}_{2} \mathrm{~S}_{3}$ under vacuum whilst ramping to $375{ }^{\circ} \mathrm{C}$. Initial rehydrogenation at $125{ }^{\circ} \mathrm{C}$ under a $\mathrm{H}_{2}$ pressure of 85 bar yielded 1.36 wt. $\% \mathrm{H}_{2}$ absorption but required $24 \mathrm{~h}$ to reach this value. ${ }_{10}$ Subsequent re-hydrogenation, using the same sample, at $200{ }^{\circ} \mathrm{C}$, Figure 5 (a), revealed the hydrogen absorption capacity and rate
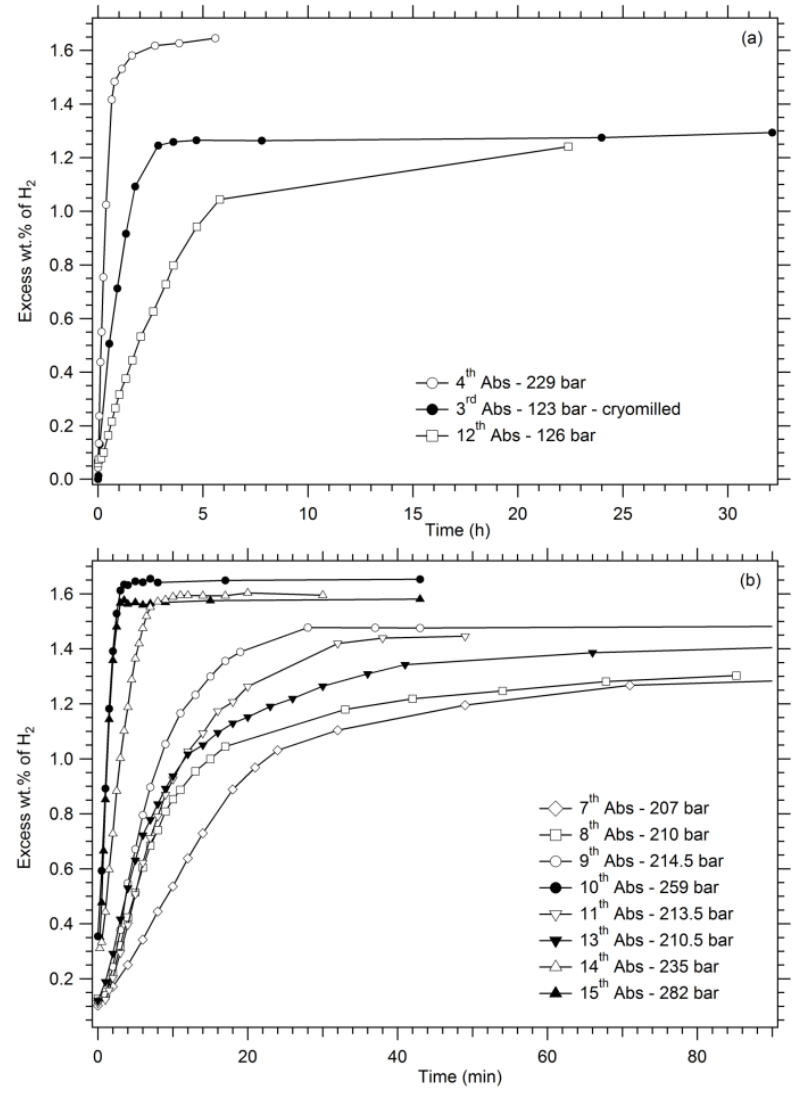

Fig 5. (a) Hydrogen absorption at $200{ }^{\circ} \mathrm{C}$ on $\mathrm{NaAlH}_{4}-\mathrm{Al}_{2} \mathrm{~S}_{3}$ milled for $6 \mathrm{~h}$ or cryomilled for 30 minutes. (b) Hydrogen absorption at $300{ }^{\circ} \mathrm{C}$ on $\mathrm{NaAlH}_{4}-\mathrm{Al}_{2} \mathrm{~S}_{3}$ milled for $6 \mathrm{~h}$.

to be dependent on the milling method, the applied hydrogen pressure and cycle number. Under an applied hydrogen pressure of 123 - 126 bar, $\mathrm{NaAlH}_{4}-\mathrm{Al}_{2} \mathrm{~S}_{3}$ cryomilled for 30 minutes or ball-milled for $6 \mathrm{~h}$ both absorbed comparable amounts of 20 hydrogen but at different rates. $\mathrm{NaAlH}_{4}-\mathrm{Al}_{2} \mathrm{~S}_{3}$ cryomilled for 30 minutes absorbed 1.25 wt. $\%$ of $\mathrm{H}_{2}$ in $3 \mathrm{~h}$ and then slowly absorbed up to 1.36 wt.\% over the next $48 \mathrm{~h}$. In contrast, $\mathrm{NaAlH}_{4}-\mathrm{Al}_{2} \mathrm{~S}_{3}$ ball-milled for $6 \mathrm{~h}$ only reaches 1.05 wt.\% of $\mathrm{H}_{2}$ absorption after $6 \mathrm{~h}$ and reaches $1.25 \mathrm{wt} \%$ after $24 \mathrm{~h}$ absorption. ${ }_{25}$ An increased $\mathrm{H}_{2}$ pressure, 229 bar, resulted in both an increased $\mathrm{H}_{2}$ uptake and absorption rate. In this case, $\mathrm{H}_{2}$ absorption reached 1.50 wt. $\%$ within $1 \mathrm{~h}$ and reached 1.65 wt. $\%$ in $6 \mathrm{~h}$. This increased capacity suggests that the absorption measurements at lower pressure had either not reached completion due to kinetic 30 restrictions or that a second absorption step (requiring higher pressure) occurred between 1.36 wt. $\%$ and 1.65 wt. $\%$ of $\mathrm{H}_{2}$. In order to assess these possibilities, absorption was subsequently performed, on the same sample, at $300{ }^{\circ} \mathrm{C}$ where the kinetics should be improved. Figure 5 (b) shows the hydrogen kinetics 35 and hydrogen uptake as a function of time, applied hydrogen pressure and absorption cycle. With an applied hydrogen pressure of between 207 and 214.5 bar, the hydrogen uptake varied between 1.39 and 1.47 wt.\%, respectively, and the time required to reach these values varied between 30 minutes and $15 \mathrm{~h}$. 40 Increasing the applied pressure to 235 bar resulted in near full absorption in $\sim 10$ minutes while increasing the pressure further still to 259 bar or above reduced this time to 3 - 4 minutes.

The high temperature, $300{ }^{\circ} \mathrm{C}$, combined with the destabilization of the system, relative to pure $\mathrm{NaAlH}_{4}$, necessitates high $\mathrm{H}_{2}$ 45 pressures for reabsorption (a minimum $\mathrm{H}_{2}$ pressure of 204 bar at $300{ }^{\circ} \mathrm{C}$ was required to initiate absorption). The system reaches absorption equilibrium in 3 - 4 minutes when the applied $\mathrm{H}_{2}$ pressure is greater than 259 bar at $300{ }^{\circ} \mathrm{C}$ and suggests that insufficient $\mathrm{H}_{2}$ pressure is the limiting factor to promote 50 hydrogenation rather than kinetics. To test this theory, experiments need to be performed under higher pressure at 300 ${ }^{\circ} \mathrm{C}$ or the kinetics need to be improved at lower temperatures.

Hydrogen desorption at $300{ }^{\circ} \mathrm{C}$ was performed against a hydrogen back pressure between 63 and 76 bar, Figure S5. In all 55 cases, desorption is exceedingly fast with hydrogen release essentially complete within 2 minutes. This demonstrates that there are clearly two different kinetic mechanisms controlling the absorption and desorption processes.

Ex-situ SR-XRD (Figure S6) was performed on the sample 60 hydrided at $300{ }^{\circ} \mathrm{C}$ under 282 bar $\mathrm{H}_{2}$ pressure (absorption cycle number 15 from Figure 5(b)) and revealed the major phases to be $\mathrm{Al}, \mathrm{NaAlH}_{4}$ and the $\delta$-phase. A minor amount of NaHS and residual $\mathrm{Na}_{2} \mathrm{~S}$ was also observed. From Figure $\mathrm{S} 6$ the $\delta$ - phase was successfully indexed as monoclinic (possible space group of ${ }_{65} \mathrm{P} 2$ or P21) with unit cell parameters of $a=9.680 \pm 0.007 \AA, b=$ $6.829 \pm 0.007 \AA, c=9.489 \pm 0.007 \AA, \beta=67.44 \pm 0.05^{\circ}$ and $\mathrm{a}$ unit cell volume of $579 \AA$.

\section{Conclusions}

The addition of $\mathrm{Al}_{2} \mathrm{~S}_{3}$ acts to effectively thermodynamically 70 destabilize sodium aluminium hydride. The decomposition occurs via complex reaction pathways with numerous, as-yet, unknown intermediate phases.

Hydrogen desorption is kinetically limited at low temperature but hydrogen can be released at temperatures lower than $100{ }^{\circ} \mathrm{C}$ for ${ }_{75} \mathrm{NaAlH}_{4}-\mathrm{Al}_{2} \mathrm{~S}_{3}$. Hydrogen absorption requires high temperatures $\left(200{ }^{\circ} \mathrm{C}-300{ }^{\circ} \mathrm{C}\right)$ and, consequently, high pressures to overcome slow absorption kinetics. A stable reversible hydrogen capacity of $1.65 \mathrm{wt} \%$ was measured at $300{ }^{\circ} \mathrm{C}$. The potential for higher hydrogen absorption requires either improving the kinetics at ${ }_{80}$ lower temperatures so that lower pressures can be used or higher hydrogen pressure at $300{ }^{\circ} \mathrm{C}$.

The multitude of unknown phases that exist in this system warrants isolation and further investigation. These phases may be viable as hydrogen storage materials in their own right or as 85 components in reactive hydride composites. The use of sulphurcontaining compounds as thermodynamic destabilizing agents is a novel method for hydrogen storage that now opens up a 
research avenue to study a range of other complex hydride systems with sulphur-based destabilization agents.

\section{Acknowledgements}

C.E.B, D.A.S and M.P acknowledge the financial support of the 5 Australian Research Council (ARC) for ARC Linkage grant LP120101848 C.E.B, D.A.S and M.P also acknowledge that part of this research was undertaken on the Power Diffraction beamline at the Australian Synchrotron, Victoria, Australia. C.E.B. also acknowledges ARC LIEF grants LE0775551 and 10 LE0989180, which enabled the XRD and gas sorption studies to be done. The Danish Strategic Research Council is acknowledged for financial support the project HyFillFast, while the Danish National Research Foundation is thanked for funding to the Center for Materials Crystallography. Finally, we are thankful to 15 MAX-lab for the provision of beam time.

\section{Notes and references}

${ }^{a}$ Department of Imaging and Applied Physics, Fuels and Energy Technology Institute, Curtin University, GPO Box U1987, Perth 6845, WA, Australia. Fax: 6189266 2377; Tel: 6189266 1381; E-mail: 20 drew.sheppard@gmail.com

${ }^{b}$ Interdisciplinary Nanoscience Center (iNANO) and Department of Chemistry, University of Aarhus, DK-8000, Denmark.

$\dagger$ Electronic Supplementary Information (ESI) available: Additional XRD, in-situ and ex-situ SR-XRD, FTIR, TPD and hydrogen desorption 25 kinetic data. See DOI: 10.1039/b000000x/

1. D. Abbott, Proceedings of the IEEE, 2010, 98, 24.

2. L. H. Rude, T. K. Nielsen, D. B. Ravnsbæk, U. Bösenberg, M. B. Ley, B. Richter, L. M. Arnbjerg, M. Dornheim, Y. Filinchuk, F.

30 Besenbacher and T. R. Jensen, Physica Status Solidi A, 2011, 208, 1754-1773.

3. B. Bogdanović and M. Schwickardi, Journal of Alloys and Compounds, 1997, 253-254, 1-9.

4. B. C. Hauback, Zeitschrift für Kristallographie, 2008, 223, 636-648.

35 5. M. P. Pitt, P. E. Vullum, M. H. Sørby, H. Emerich, M. Paskevicius, C. E. Buckley, J. C. Walmsley, R. Holmestad and B. C. Hauback, The Journal of Physical Chemistry C, 2012, 116, 14205-14217.

6. M. P. Pitt, P. E. Vullum, M. H. Sorby, D. Blanchard, M. P. Sulic, H. Emerich, M. Paskevicius, C. E. Buckley, J. C. Walmsley, R.

40 Holmestad and B. C. Hauback, Journal of Alloys and Compounds, 2012, 513, 597-605.

7. J. M. Bellosta von Colbe, O. Metz, G. A. Lozano, P. K. Pranzas, H. W. Schmitz, F. Beckmann, A. Schreyer, T. Klassen and M. Dornheim, International Journal of Hydrogen Energy, 2012, 37,

$45 \quad$ 2807-2811.

8. M. P. Pitt, P. E. Vullum, M. H. Sørby, H. Emerich, M. Paskevicius, C. J. Webb, E. M. Gray, C. E. Buckley, J. C. Walmsley, R. Holmestad and B. C. Hauback, International Journal of Hydrogen Energy, 2012, 37, 15175-15186.

50 9. S. V. Alapati, Johnson, J. K., Sholl, D. S., Journal of Physcal Chemistry C, 2008, 112, 5258 - 5262.

10. B. Bogdanović, R. A. Brand, A. Marjanović, M. Schwickardi and J. Tölle, Journal of Alloys and Compounds, 2000, 302, 36-58.

11. B.-M. Lee, J.-W. Jang, J.-H. Shim, Y. W. Cho and B.-J. Lee, Journal

55 of Alloys and Compounds, 2006, 424, 370-375.

12. HSC Chemistry, Outotech Research Oy, 2007.
13. G. A. Lozano, C. N. Ranong, J. M. Bellosta von Colbe, R. Bormann, J. Hapke, G. Fieg, T. Klassen and M. Dornheim, International Journal of Hydrogen Energy, 2012, 37, 2825-2834.

60 14. A. Ulman, Chemical Reviews, 1996, 96, 1533-1554.

15. O. Voznyy and J. J. Dubowski, The Journal of Physical Chemistry C, 2008, 112, 3726-3733.

16. T. R. Jensen, T. K. Nielsen, Y. Filinchuk, J.-E. Jørgensen, Y. Cerenius, E. M. Gray and C. J. Webb, Journal of Applied

65 Crystallography, 2010, 43, 1456-1463.

17. N. V. Y. Scarlett and I. C. Madsen, Powder Diffraction, 2006, 21, 278-284.

18. M. P. Pitt, M. Paskevicius, C. J. Webb, D. A. Sheppard, C. E. Buckley and E. M. Gray, International Journal of Hydrogen Energy, $70 \quad 2012,37,4227-4237$.

19. P. A. Anderson, P. A. Chater, D. R. Hewett and P. R. Slater, Faraday Discussions, 2011, 151, 271-284.

20. A. Borgschulte, M. O. Jones, E. Callini, B. Probst, S. Kato, A. Züttel, W. I. F. David and S.-i. Orimo, Energy \& Environmental Science,

$75 \quad 2012, \mathbf{5}, 6823-6832$

21. F. Haarmann, H. Jacobs and W. Kockelmann, The Journal of Chemical Physics, 2000, 113, 6788-6794.

22. S. Gomes, G. Renaudin, H. Hagemann, K. Yvon, M. P. Sulic and C. M. Jensen, Journal of Alloys and Compounds, 2005, 390, 305-313.

80 23. K. Beckenkamp, H. D. Lutz, H. Jacobs and U. Metzner, Journal of Solid State Chemistry, 1994, 109, 241-250.

24. R. E. Eibeck and B. D. James, Inorganic Syntheses, 1963, 7, 128131.

25. E. C. Ashby and B. D. James, Inorganic Chemistry, 1969, 8, 2468852472.

26. J. R. Ares, K.-F. Aguey-Zinsou, F. Leardini, I. J. m. Ferrer, J.-F. Fernandez, Z.-X. Guo and C. Sánchez, The Journal of Physical Chemistry C, 2009, 113, 6845-6851. 